\title{
Sciendo MARINE PROPULSION SYSTEM VIBRATION SENSOR HEADS
}

DOI 10.2478/ntpe-2018-0092

\author{
prof. dr hab. inż. Piotr Bielawski \\ Maritime University of Szczecin, Poland
}

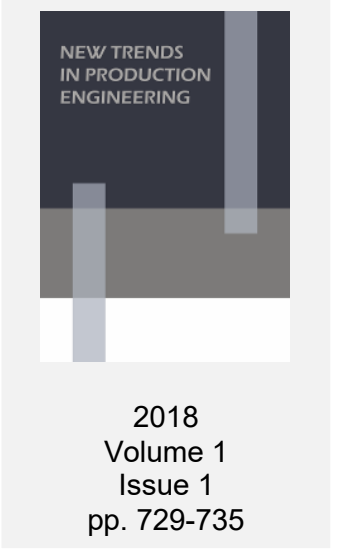

\begin{abstract}
Vibration symptoms are the main symptoms used for diagnosing machines. This applies mainly to vibrations of non-rotating machines. Symptoms of rotating element vibrations are used in a limited scope, while mostly used are the symptoms of radial vibrations of rotating shafts. Across industries, the use of technical vibration diagnosis varies. Marine propulsion systems are poorly equipped with diagnostic equipment of that type. One of the main reasons is lack of appropriate sensors. The study presents two solutions of sensor heads. One solution applies to a sensor head built into the free end of the crankshaft of a reciprocating machine. The shaft free end sensor allows measurement of torsional and longitudinal vibration accelerations of the free end as a function of shaft rotation. The other solution refers to a sensor head built into sealed slide bearing of a straight shaft. The slide bearing head enables measurement of the eccentricity to the journal relative to the shell. Sensor heads under consideration are particularly suitable to be built in the ship's propulsion system and integrated with the ship's maintenance system. Sensors of the ship's maintenance system equipped with these heads will allow the operator to draw conclusions concerning the wear margins of the propulsion engine and that of the tail shaft.
\end{abstract}

Keywords: vibration of machines, marine propulsion systems, vibration symptoms, sensors, sensor heads

\section{INTRODUCTION}

Vibrations and wear of elements are processes affecting working machines. There is a feedback between wear and vibrations. Vibrations are deemed undesirable, hence attempts are made to eliminate or at least substantially reduce them. Wear of a machine leads to wear margin decrease until it is completely exploited. It is justified to take remedial actions aimed at machines and other technical items to efficiently and effectively restore their wear margin. The first of remedial actions is the identification of the margin - identification of the characteristics that undergo changes along with the degradation of a functional unit. Vibration signals may have diagnostic value for the identification of machine wear margin. Vibration signals are also used to identify the wear margin of some functional units of a machine.

To identify a wear margin of a machine based on measured vibrations, we have to use proper methods and means for measuring and evaluating vibrations. Methods and means of vibration measurement and evaluation are described in standards ISO 20816, ISO 10816 and ISO 7919. They include a two-step description: general guidelines, describing methods and means for all machines, and a detailed description of boundary values for $\mathrm{s}$ specific group of machines.

ISO 20816-1:2016 Mechanical vibration - Measurement and evaluation of machine vibration. Part 1: General guidelines. ISO 20816-2:2017 Part 2: Land-based gas turbines, steam turbines and generators in excess of $40 \mathrm{MW}$, with fluid-film bearings and rated speeds of $1500 \mathrm{r} / \mathrm{min}$, $1800 \mathrm{r} / \mathrm{min}, 3000 \mathrm{r} / \mathrm{min}$ and $3600 \mathrm{r} / \mathrm{min}$.

ISO 10816-3:2009 Mechanical vibration - Measurement and evaluation of machine vibration. Part 3: Industrial machines with nominal power above $15 \mathrm{~kW}$ and nominal speeds between 120 $\mathrm{r} / \mathrm{min}$ and $15000 \mathrm{r} / \mathrm{min}$ when measured in situ. ISO 10816-4:2009 Part 4: Gas turbine sets with fluid-film bearings. ISO 10816-5:2000 Part 5: Machine sets in hydraulic power generating and pumping plants. ISO 10816-6:1995 Part 6: Reciprocating machines with power ratings above 100 kW. ISO 10816-7:2009 Part 7: Rotodynamic pumps for industrial applications, including 
measurements on rotating shafts. ISO 10816-8:2014 Part 8: Reciprocating compressor systems.

ISO 7919-3:2009 Part 3: Mechanical vibration - Evaluation of machine vibration by measurements on rotating shafts. Coupled industrial machines. ISO 7919-4:2009 Part 4: Gas turbine sets with fluid-film bearings. ISO 7919-5:2005 Part 5: Machine sets in hydraulic power generating and pumping plants.

Despite significant problems with vibrations, marine propulsion systems are not subject to detailed description in the above standards. The use of vibrations as diagnostic signals in shipbuilding is limited, too. The reason may be that propulsion systems have their specific characteristics and require separate treatment, inter alia, the use of special sensors.

\section{THE SPECIFICITY OF MARINE PROPULSION SYSTEMS}

Marine propulsion systems consist of a propeller, tail shaft and sealing, thrust bearing and a prime mover, usually a slow or medium speed diesel engine. Additionally, there is a reduction gear or a gear for transferring power to the generator.

The length of the whole system, mounting on a deforming foundation (ship's hull), existence of variable forces of propeller reaction and variable forces in the engine are factors contributing to vibrations of the shafting: longitudinal, torsional and radial vibrations.

In marine propulsion systems, shafts are generally supported by slide bearings:

- slide radial bearings;

- slide longitudinal bearings: thrust and locating bearings;

- slide bearings of guide type.

Each machine being a component of a propulsion system has sealing on both ends. Shaft sealing is particularly important and complex. Shafts of individual machines are connected through the clutch or toothed gear transmission.

The requirements concerning the measurement and vibration assessment on ships are set forth in regulations issued by classification societies, such as the Polish Register of Shipping (PRS) (PRS, 2017b). According to the PRS publication (PRS, 2004), the main objective of classification bodies in this field is preventing vibrations on ships, not using them for the evaluation of wear margin in the sense presented in (Bielawski, 2016a).

A large number of slide bearings makes marine propulsion systems suitable for the use of rotating elements vibrations for the identification of their wear margin.

Slide bearings should be able to: maintain fluid friction; maintain the shaft/shaft journal in a specified position; damp vibrations and impact affecting the bearing journals.

Liquid friction is necessary to ensure the required efficiency of the bearings and reliability. The measure associated with liquid fractions the thickness of oil film.

In the case of labial sealing it is required that the eccentricity of the sealed journal relative to the sealing housing should not exceed a specified value, otherwise leakage may occur (Tietze, 2003). In the case of multiple support shafts it is required that the journal centers at points of shaft support should be in one specific line. Non-compliance with this condition may result from the loss of wear margin by one of the bearings and may cause the formation of additional bending stresses. In the case of crankshafts the so called shaft deflection is a measure of shaft deformation.

Deformations as a result of vibrations and loads of different sign may cause displacement of the journal in the bearing 'from wall to wall', which may cause impact and fatigue damage of the shell material. The impact force depends on damping in the bearing, while the damping may depend on bearing wear margin. In diesel engines, symptoms may be certain measures of bearing housing vibration, as well as longitudinal and torsional vibrations of the crankshaft. It is therefore necessary to find methods and means for operational measurement of oil film thickness, deflection of the rotating shaft, longitudinal vibration from impacts and torsional vibrations associated with bearings in the engine.

Based on previous research, it has been established that for the identification of the wear margin of functional units in a marine propulsion system the following means are needed: 
- a sensor for measuring the eccentricity of the journal in the bearing of the tail shaft;

- a sensor of axial displacement in a thrust bearing;

- a sensor on the shaft free (non-driven) end;

- a sensor of axial displacement in the locating bearing of the engine.

Sensor heads make up a principal component of vibration sensors. Location of sensor heads in a ship's propulsion system is shown in Figure 1.

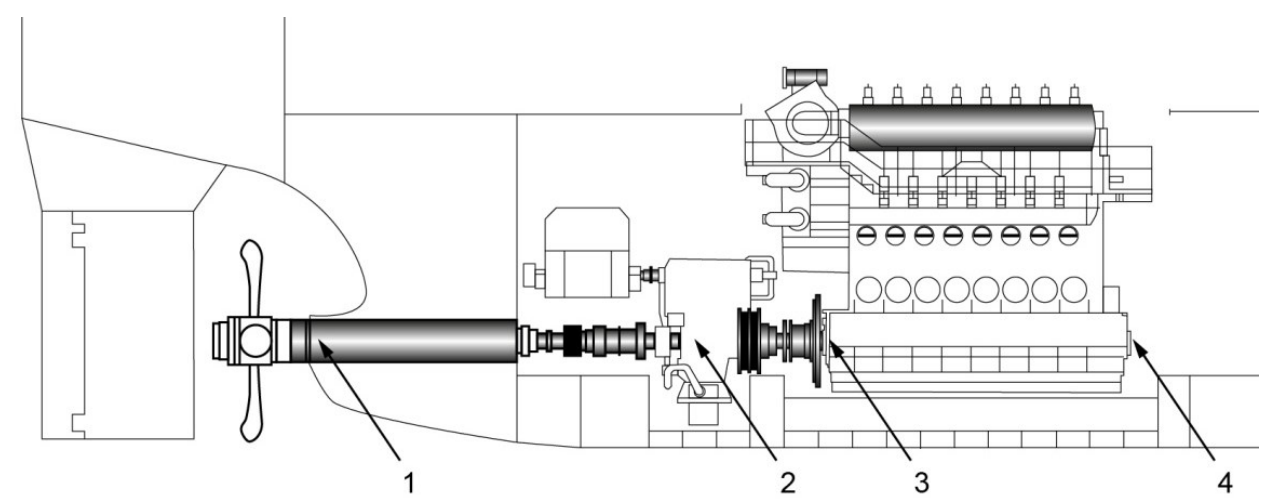

Fig. 1 Location of sensors in the ship's propulsion system:

1 - head for measuring the eccentricity of the journal in the bearing of the tail shaft,

2 - sensor head for axial displacements in a thrust bearing,

3 - sensor head of axial displacements in a locating bearing or engine sealing, 4 - sensor head of the crankshaft free end

\section{THE HEAD FOR MEASURING ECCENTRICITY}

Marine tail shaft bearings are subject to mandatory technical supervision of a classification society. It follows from (PRS, 2004; 2017a) that the user is obliged to carry out:

- continuous measurement of the temperature of bearing shell;

- periodic measurement of oil properties;

- additionally, periodic measurement of shaft misalignment, with the unit disconnected.

The method for measuring the shaft misalignment was described in (Patent Office, 1955). Measurement of shaft misalignment by that method requires shaft stoppage and installation of a special measuring instrument.

The results of the above mentioned measurements do not permit to diagnose and predict the tail shaft bearing wear margin. The solution may be the inferences about oil film thickness in the bearing from continuous measurements of journal eccentricity in the shell.

The sensor head for eccentricity measurement is to be embedded into the slide bearing, particularly a sealed bearing, and may be used for measurements of the eccentricity of shaft journal relative to tail shaft bearing shell.

Position of the journal in the shell is dependent on the rotary speed (Fig. 2).
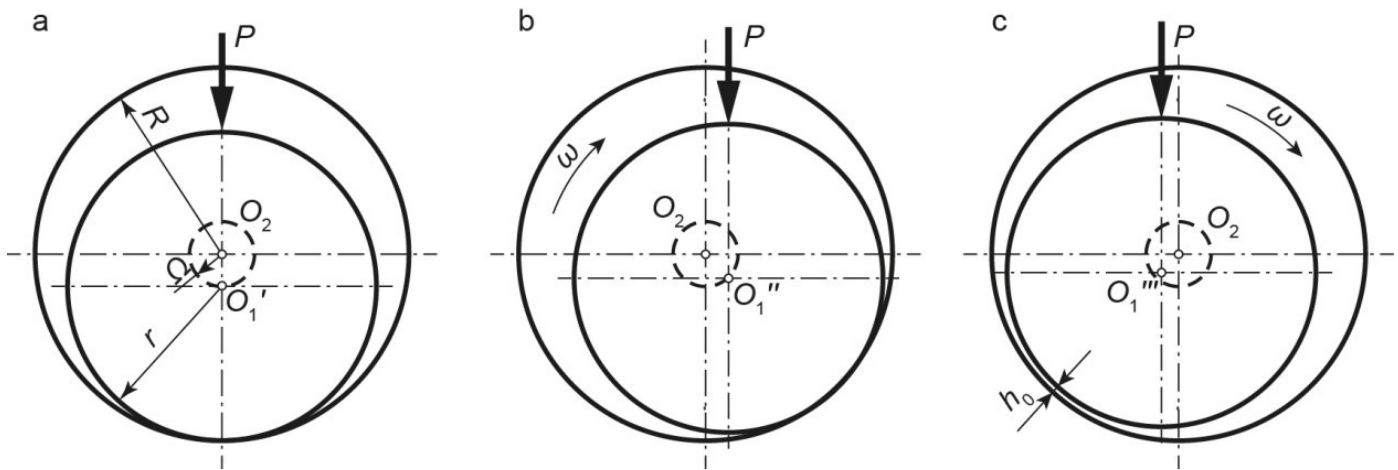

Fig. 2 Position of the journal in the shell of a slide bearing:

a - motionless journal, $b$ - slow rotation of the journal during start-up,

c - journal position at fluid friction, $O_{1}$ - centre of journal, $O_{2}-$ centre of shell, $P$ - load,

$\omega-$ angular velocity, $\Omega=R-r$ radius of clearance circle, $h_{0}-$ minimum thickness of oil film Source: (Bielawski, 2017a) 
The thickness of the oil film $h_{0}$ is mainly affected by a dimensionless quantity - Sommerfeld number So.

$$
\text { So }=\frac{P \psi^{2}}{b d \eta \omega}
$$

where:

$\psi$ - relative clearance,

$\eta$ - dynamic viscosity of lubricating oil,

$d$ - width of the bearing shell.

With unchanging viscosity, length and diameter and steady clearance, an increase in shaft speed tending to infinity will cause the journal centre to move along a trajectory similar to a semicircle. The existence of a variable load, the anisotropy of the shaft and bearing, and the frequency of shaft's free vibrations lead to a situation where the trajectory is not a point but a figure with a significant value of the radius-vector, Fig. 3 (Bielawski, 2017a).

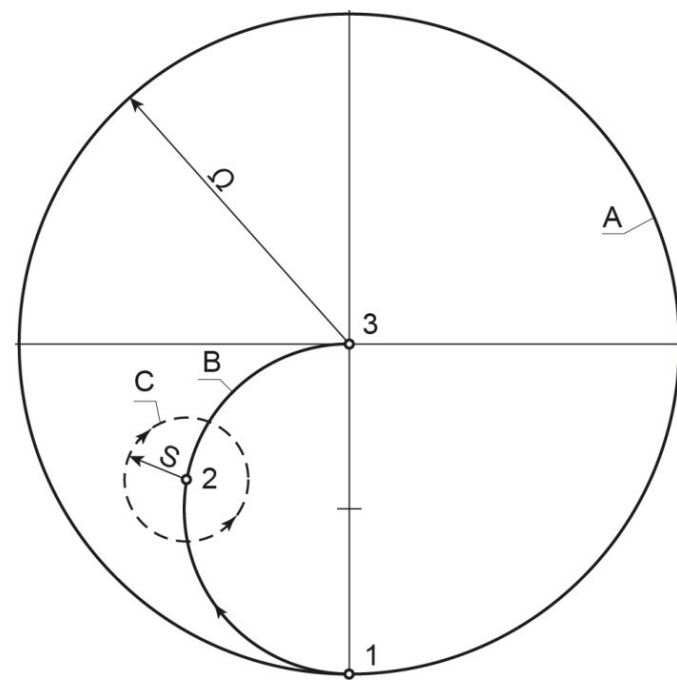

Fig. 3 A trajectory of journal centre:

$\Omega$ - radius of clearance circle, $A$ - clearance circle, $B$ - path of average values of journal centre, C - path of trajectory variable component, 1 - detachment of the journal from the shell, 2 - mean value of trajectory for a specific speed,

Source: (Bielawski, 2017a)

\section{3 - theoretical position of journal centre for speeds tending to infinity}

Example trajectories of the journal centre measured on a model of the tail shaft are shown in (Bielawski, 2011).

The slide bearing wear results in:

- increased clearance $s=D-d$;

- and/or decrease in viscosity $\eta$.

Increased clearance leads to an increase in Sommerfeld number. A decrease in viscosity increases Sommerfeld number. The inverse of Sommerfeld number is the substitute measure of a slide bearing wear margin. The mean value of journal eccentricity in the shell measured at a specific angular velocity (Bielawski, 2017a) can be a symptom of the slide bearing wear margin.

For the measurement of the journal in the shell eccentricity we can use a measuring system described in (PN-ISO 7919-1). The system consists of two sensors of displacement, with the heads set perpendicular to each other in one plane perpendicular to the axis of the journal, Fig. 4. Contrary to the measurement of trajectory variable component, to measure eccentricity we have to calibrate the sensors.

The calibration of the sensors consists in establishing values of $X$ and $Y$ for journal-shell concentricity, i.e. eccentricity $e=0$, Fig. 4 . The sensor heads should be set so that sensor indications are in the middle of sensor linear range. Indications $X$ and $Y$ are assigned zero value of eccentricity. 


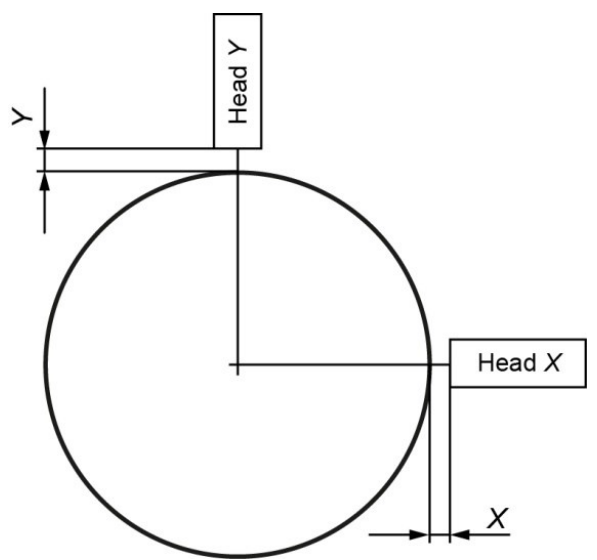

Fig. 4 Positioning of the sensor heads against the shaft journal: $X$ - distance between the generatrix of the journal and the front face of the head $Y$

The method of mounting and calibrating the sensor heads is subject to patent claims (Bielawski, 2017b). Figure 5 shows the solution, where sensor heads are placed in a ring attached to the bearing shell.

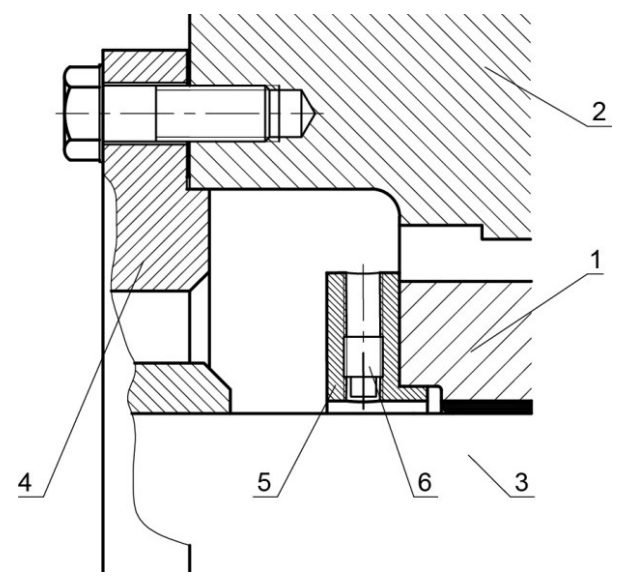

Fig. 5 Sensor heads 6 placed in a ring 5 attached to shell 1 of the tail shaft bearing: 1 - bearing shell, 2 - ship's hull, 3 - shaft, 4 - sealing, 5 - sensor head,

Source: (Bielawski, 2017b)

6 - ring for sensor head attachment

The calibration of the sensor system is made by means of a standard shell with the diameter equal to the nominal diameter of the journal. Sensors whose heads are placed in a ring attached to the shell are calibrated before the shaft assembly and before attaching the ring to the shell, Fig. 6. After inserting the standard shell into the ring holding sensor heads, the shell and ring axes should be aligned.

During machine operation, observation is conducted to note mean values of the difference between $\Delta X$ and $\Delta Y$, between an actual value and zero value.

$$
\begin{gathered}
(\Delta X)^{2}+(\Delta Y)^{2}=e^{2} \\
e=1 / 2 s-h_{0}
\end{gathered}
$$

During machine use, the clearance $s$ is not a constant value. It increases due to wear. Increased clearance leads to an increase in the Sommerfeld number: $S_{0}=f(s)$ and $h_{0}=f\left(S_{0}\right)$.

Having measured the value of eccentricity $e$, and assuming constant load, known viscosity and speed, we can estimate, using e.g. diagrams from (DIN31652), actual clearance and actual oil film thickness.

The thickness of the oil film can be also defined as the difference between the current eccentricity and previously measured eccentricity for zero value of shaft rotary speed:

$$
h_{0}=e_{k}-e_{a}
$$



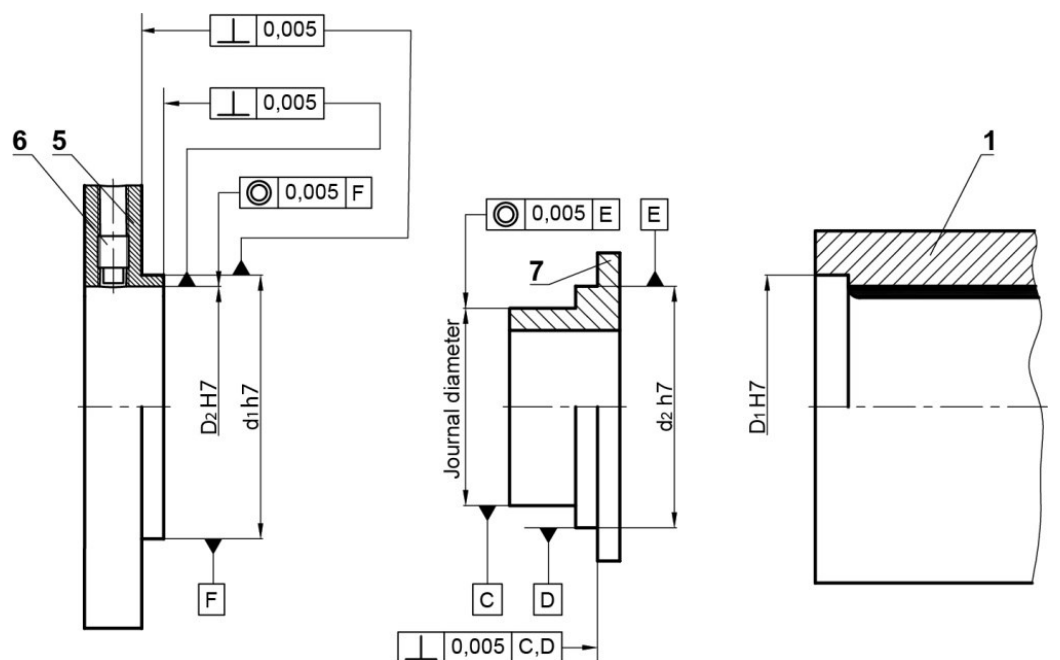

Fig. 6 The calibration of sensors by means of a standard shell:

1 - bearing shell, 5 - ring for sensor head attachment, $\mathbf{6}$ - sensor head, $\mathbf{7}$ - standard shell Source: (Bielawski, 2017b)

Since the allowable misalignment/eccentricity in the sealing is comparable with $1 / 2$ of allowable bearing clearance, then condition monitoring of a bearing by eccentricity measurements means that the adjacent sealing is also monitored.

The use of a diagnostic system using signals dependent on the eccentricity of the shaft will bring about effective diagnosis of the bearing and condition monitoring of the sealing: it will eliminate the need for periodic shaft misalignment measurement, increase the tail shaft reliability and reduce ship's operational costs.

\section{THE SENSOR HEAD OF THE SHAFT FREE END VIBRATION}

The free end of a crankshaft is a place without vibration nodes, and torsional and longitudinal vibration amplitudes of the propulsion unit reach significant values (propulsion unit understood as a diesel engine and power receiver or an engine and a piston machine). The head of free end vibration sensor, Figure 7, serves for positioning and mounting the heads of transducers, components of free end vibration sensor. The free end vibration sensor head is composed of the moving part - the rotor, and stationary elements. The head rotor is fixed to the crankshaft free end front face, making up its extension. Non-moving elements make up a part mounted directly on the machine/engine body and a part bearing-mounted on the rotor and connected through a bellows coupling with the machine body. The head of free end vibration sensor is currently a subject of patent application (Bielawski, 2016b).

The head of free end vibration sensor is used for the simultaneous measurement of:

- torsional vibration acceleration of shaft free end;

- path of longitudinal vibrations of the shaft free end;

- distinguished angular position of the shaft free end;

- longitudinal vibration acceleration of the shaft free end.

The relations between the free end vibration measure and a measure of the wear margin of propulsion system units have been described in, inter alia (Bielawski, 1991; 2002; 2005; 2009; 2012).

Crankshaft torsional vibrations of a unit are a subject of many studies that aim at their use for calculating the forces in engine cylinders and the inference about the wear margin of functional units of a generating set. Symptoms of torsional vibration of the free end allow us to infer about the wear margin of bearings located in vibration nodes (Bielawski, 1991). Due to the dependence of mass forces on acceleration, it is recommended to measure the acceleration of torsional vibration. Measurements of torsional vibration acceleration can be indirect, whereas accelerations are calculated by differentiating the measured rotation angles as a function of time or by direct measurement by a sensor, on the basis of Ferraris principle. Sensors using the Ferraris principle are described in (Hiller, 2003). 


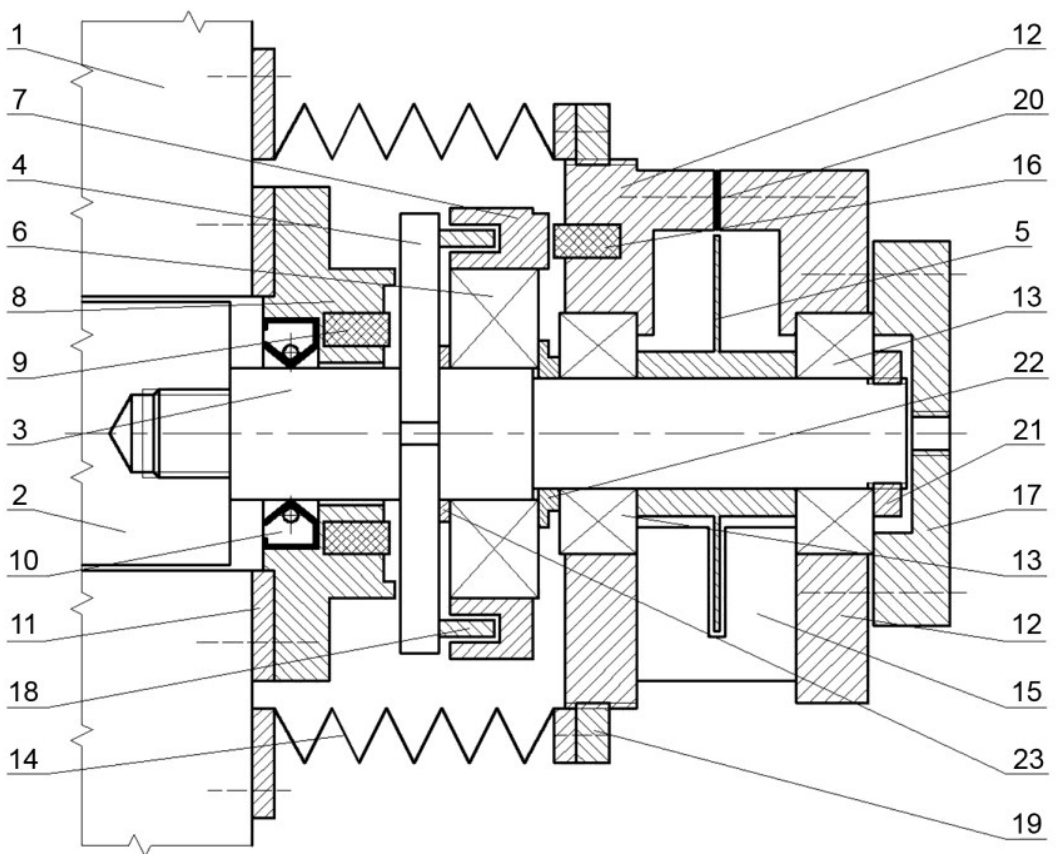

Fig. 7 The sensor head of crankshaft free end:

1 - machine body, 2 - free end of the machine shaft, 3 - measuring shaft of the integrated head, 4 - measuring-mounting disk made with the shaft (or permanently connected), 5 - measuring disk mounted on a shaft, 6 - disk bearing (7), 7 - measuring disk with elastic mounting on a shaft, 8 - fixed disk connected with machine body, 9 - probe of longitudinal vibration path sensor, 10 - sealing of the measuring shaft, 11 - fixed disk distance shim (8), 12 - split body of the torsional vibration sensor head, 13 - bearing of torsional vibration sensor head body, 14 - bellows coupling connecting the machine body and the sensor head body,

15 - sensor probe of torsional vibration acceleration, 16 - sensor probe of the indicated distinguished angular position of the shaft, 17 - non-rotating disk of the sensor of absolute longitudinal vibration accelerations, 18 - disk driver (7), 19 - adjusting-locating nut, 20 - shim,

Source: (Bielawski, 2016b) 21 - nut, 22 - spacer ring, 23 - spacer ring

Longitudinal vibrations of the free end are composed of vibrations resulting from axial displacement of main journals and transitive vibrations generated by pulse components of journal loads. Amplitudes and mean values of periodic displacements of journals depend on the position of the shells as supports of the crankshaft and should be measured as displacements/paths of vibrations (Bielawski, 2005). Transitive forces are dependent on the wear margin of crank bearings and the vibrations generated by these forces should be measured as accelerations of vibration (Bielawski, 1991; 2002).

For vibration analysis we need a signal of marked angular position. The direct measurement on the shaft is burdened with an error due to the amplitude of torsional vibration at the point of measurement. It is proposed to use in the solution here presented the so called seismic mass, not participating in vibrations (see transducers of absolute vibration, Geiger's torsion meter) and to measure the marked position on that mass.

In the solution according to (Bielawski, 2016b) the measurement of shaft longitudinal vibration path is a non-contact measurement of a gap between the end face of the head (9) and end face of the disk (4), Fig. 7. Simultaneous measurement by two heads (transducers) located close to the shaft axis followed by the averaging of the results will reduce measurement errors caused by shape deviations and bending vibration of the shaft.

According to (Bielawski, 2016b), a radial notch or integral key on the disk (7) is used for measuring a marked angular position in the free end sensor. Passing of that element before the sensor face end (16) produces a pulse signal. An elastic connection of the disk (7) on a bearing delays its movement in proportion to shaft (3) movement.

Measurement of torsional vibration acceleration by a free end sensor is a measurement of disk vibration (5) relative to the head (15) of the transducer operating on the Ferraris principle, Fig. 7. The required purity of disk rotation relative to the head (15) is assured through non-clearance 
mounting of the sensor head housing (12) in two precise oblique bearings (13). The required lack of freedom of head (15) rotary movement relative to the shaft (3) axis is provided by connecting the sensor head (12) and the machine (1) body via a bellows coupling, rigid to twisting, susceptible to bending and compression.

Longitudinal vibration acceleration by the shaft free end sensor is measured by means of absolute vibration transducer, e.g. piezoelectric transducer bolted to a non-rotating disk (17): longitudinal vibration of the rotating shaft is transferred onto the disk through non-clearance mounted bearings (13), Fig. 7 .

\section{CONCLUSION}

The presented design solutions apply to a sensor head for measurements of the journal-shell eccentricity and a sensor head of the shaft free end. The usefulness of the proposed solutions has been confirmed in single tests conducted under laboratory conditions.

Further studies are needed using complete and precisely made sensor heads. Tests should be carried out on a real model of a propulsion system, followed by field tests in real conditions.

In compliance with asset management, it is recommended to include the sensor head in the construction of a propulsion system and the plan of propulsion system maintenance system.

The head for measuring journal eccentricity relative to the shell can be used for all slide bearings, with or without sealing. In the case of propulsion systems, a sensor for thrust bearing displacements and a methodology of evaluating the thrust bearing wear margin should be considered.

The head of the shaft free end can be applied to all machines with crank-piston mechanism. If other devices are already connected to the free end of the shaft, certain design changes are needed in the machine. For instance, in reciprocating compressors an oil pump shaft is mounted on the free end. Oil pump can be driven by an electric motor. Classification society regulations addressing marine engines require that the design of a damper installed on the free of the crankshaft should enable a connection of torsional vibration measuring devices.

The free end sensor should be integrated with a sensor of displacements placed in the locating bearing or sealing. The cooperation of both sensors allows full diagnostic inference. One distinct feature of the solution is that the shaft free end sensor permits performing measurements of absolute longitudinal vibrations of the shaft and produces a signal of specified angular position without disturbances of torsional vibration.

\section{REFERENCES}

Bielawski, P. (1991). Instandhaltungsorientierte Diagnostik an Schiffsdieselmotoren. Prace Naukowe Politechniki Szczecińskiej $\mathrm{Nr}$ 448, Szczecin: Wydawnictwo Uczelniane Politechniki Szczecińskiej.

Bielawski, P. (2002). Elementy diagnostyki mechanizmów tłokowo-korbowych maszyn okrętowych. Studia Nr 39, WSM, Szczecin.

Bielawski, P. (2005). The Diagnosing of Crankshafts. In: The 18th International Congress and Exhibition on Condition Monitoring and Diagnostic Engineering Management COMADEM 2005, Cranfield UK, 31.08 - 02.09.2005, pp. 131-142.

Bielawski, P. (2009). Condition monitoring of marine power plants. Diagnostyka 1 (49), pp. 4548.

Bielawski, P. (2011). Diagnostics of marine propeller shafts. Journal of Polish CIMAC 6 (2), pp. $31-40$.

Bielawski, P. (2012). Measurement and evaluation of mechanical vibration of reciprocating machines. Diagnostyka - Applied Structural Health, Usage and Condition Monitoring 1 (61), pp. 25-30.

Bielawski, P. (2016a). Measures and limits of machine wear margin of production systems. Problemy eksploatacji / Maintenance Problems 1, pp. 129-139.

Bielawski, P. (2016b). Zintegrowana głowica pomiarowa, zwłaszcza do badań drgań wolnego końca wału maszyn. P.419989. Wniosek o udzielenie patentu zarejestrowany w Urzędzie Patentowym RP 27.12.2016.

Bielawski, P. (2017a). Measures and symptoms of the wear margin in functional unit nodes of production system items. Journal of Machine Construction and Maintenance - Problemy Eksploatacji 3 (106), pp. 117-126. 
Bielawski, P. (2017b). Sposób montażu i wzorcowania układu do pomiaru mimośrodowości wirującego wału zwłaszcza wału łożyska ślizgowego z uszczelnieniem promieniowym. P.423510. Wniosek o udzielenie patentu zarejestrowany w Urzędzie Patentowym RP 07.12.2017.

DIN31652. Hydrodynamische Radial-Gleitlager im stationären Bereich.

Hiller, B. (2003). Ferraris Acceleration Sensor - Principle and Field of Application in Servo Drives. [online] Available at: https://pl.scribd.com/document/81194247/FerrarisAcceleration-Sensor [Accessed 25 Nov. 2018].

Patent Office (1955). Sposób stałego badania stanu wyrobienia pochwy przyśrubowej i związanego z tym opadu wału śruby statku oraz przyrząd do stosowania tego sposobu. Urząd Patentowy PRL, opis patentowy nr 37961 z dnia 25.08.1955.

PN-ISO 7919-1:2001. Drgania mechaniczne maszyn z wyłączeniem maszyn tłokowych. Pomiary drgań wałów wirujących i kryteria oceny. Część 1: Wytyczne ogólne. Polski Komitet Normalizacyjny.

PRS (2004). Polski Rejestr Statków: Zapobieganie drganiom na statkach. Publikacja informacyjna nr 2/l, Gdańsk.

PRS (2017a). Polski Rejestr Statków: Przeglądy okresowe wałów śrubowych. Publikacja nr 111/P, Gdańsk.

PRS (2017b). Polski Rejestr Statków: Przepisy klasyfikacji i budowy statków morskich. Gdańsk. Tietze, W. (Ed.) (2003). Handbuch Dichtungspraxis. Essen: Vulkan-Verlag. 